
\title{
$\begin{array}{ll}\text { Research Square } & \begin{array}{l}\text { Preprints are preliminary reports that have not undergone peer review. } \\ \text { They should not be considered conclusive, used to inform clinical practice, } \\ \text { or referenced by the media as validated information. }\end{array}\end{array}$
}

\section{Vision 2030 and Sustainable Development: State Capacity to Revitalize the Healthcare System in Saudi Arabia}

\author{
Redwan Rahman ( $\sim$ rahmanredwan@yahoo.com ) \\ King Abdulaziz University https://orcid.org/0000-0001-8757-2818 \\ Ameerah Qattan \\ King Abdulaziz University
}

\section{Research}

Keywords: Vision2030, Sustainable Development, Healthcare, State Capacity, Development, Saudi Arabia

Posted Date: August 6th, 2020

DOI: https://doi.org/10.21203/rs.3.rs-52266/v1

License: (c) (1) This work is licensed under a Creative Commons Attribution 4.0 International License. Read Full License

Version of Record: A version of this preprint was published at INQUIRY: The Journal of Health Care Organization, Provision, and Financing on January 1st, 2021. See the published version at https://doi.org/10.1177/0046958020984682. 


\section{Abstract}

Vision 2030 is seen as a contributing factor to diversifying the Kingdom of Saudi Arabia's economy and stimulating numerous changes in its social sectors, including in the health sector. Sustainable Development (SD)2030 is a global consensual agreement among nation states to build a sustainable, desirable and progressively interrelated world. Achieving the Sustainable Development 2030 is seen as a main component of development for health. This article explores the state capacity and the role of Vision2030 and Sustainable Development 2030 in the revitalizing the healthcare system in Saudi Arabia. Systematic review and thematic data analysis technique are used as method of this study. The Saudi government highlighted and emphasized Vision 2030 to improve population health and the world body emphasized that Sustainable Development 2030 will contribute to "healthy lives and promote well-being for all at all ages". Saudi Arabia's Vision2030 encourages the state to play a renewed role in development in the light of the UN's declaration of the 'right to development'. In pursuing development, the state must have necessary institutional environment in sustaining capacity, resources and interactions among groups for realizing constructive roles and functions in maintaining state affairs. The government needs to develop a sustainable healthcare system by adding to health human resources, building public-private partnership, and efficient use of resources through stewardship, good governance, accountability, and transparency.

\section{Introduction}

The Saudi constitution signifies health as one of the fundamental rights of every citizen. As it noted in Article 31 that "The state takes care of health issues and provides healthcare for each citizen." The development of population health is one of the priorities of the government which is mentioned in the subsequent national development plans and international commitments and agreements. Since the establishment of Kingdom of Saudi Arabia in 1900s, the government has been trying to provide best possible healthcare to its citizens within the economic means of the country. Vision 2030 is a historical milestone with reference to Saudi Arabia, announced in 2016, to revitalize the economy and private sector as an engine of growth and development. Sustainable Development Goals (SDGs) 2030 was declared by the global community in 2015 to transform the world towards sustainability and development. This study examined state capacity and the role of Vision 2030 and Sustainable Development 2030 in revitalizing health care systems in Saudi Arabia.

\section{Methods}

Different search engines and databases including Google Scholar, PubMed, and Scopus have been used. Relevant keywords such as "Saudi Arabia" "health" "healthcare" "health sector" "state capacity" "development" "Vision 2030" and "Sustainable Development 2030" were used. Reference studies relevant to each publication have also been considered. This article also used relevant reports and discussion papers of the World Health Organization, the World Bank, United Nations, and the International Monetary Fund. The timeframe of the articles and documents used in this research spans between 2000 and 2019, as this period is the most relevant in grasping the growth of private healthcare in Saudi Arabia. However, documents associated with government policy, planning and statistical reports are outside the purview of this timeframe. The review has also excluded non-English documents. This study is based on the systematic review of the chosen literature. The data analysis technique that has been used is thematic in nature. The analysis is focused on the agreement of thematic contents in the available sources of text or data [1] and it has helped triangulate these agreements [2].

\section{The Conceptual Framework}

\section{VISION 2030}

Since the foundation of Saudi Arabia in 1932, the visionary leadership planned for change towards growth and development. Diversification of economy and five-year plans have been a matter of priority to the successive regimes but the result was not completely successful due to abnormal fluctuation of oil prices, other national and international factors [3, 4]; and internally, the five-year plans were not fully implemented due to the perception of political repercussions by the respective regime, maintaining a status quo. Between 1980 and 2017, Saudi Arabia faced $2 \%$ and $25 \%$ budget deficiency for 22 years and $1 \%$ and $32 \%$ budget surplus for 15 years [5]. Evidently, the country could not maintain feasible budgets in the last few decades. The country faced a budget deficit of SAR367 billion in 2015 and SAR297 billion in 2016. Similarly, oil revenues in the national budget reduced from US\$277 billion, USD\$163 billion and US\$141 billion in 2014, 2015 and 2016 respectively [6]. In addition, the country was facing challenges due to population growth and fiscal deficit. The government expected to overcome these problems by reducing dependence on oil and prudent management of economy [7].

The government unveiled a determined program of development in April 2016 as 'Vision 2030' to transform the economy by 2030, [8] and National Transformation Program (NTP) 2020 was subsequently announced to achieve the goals [9]. In announcing the Vision, the 
government focused on its geographical location, the nature of the society, highlighted privatization and the need to maximize the contribution of the private sector to administer effective governance [8]. It was portrayed that Vision 2030 would contribute to doubling the GDP from its current figure, an investment of US\$4 trillion in the non-oil economy largely from private sources, six million additional Saudi nationals in the workforce, $60 \%$ increase in Saudi household income an increase in GDP to US\$8 billion [7]. The government's target of Vision 2030 had prior focus to take the economy forward - from its current position to among the first 15 nations/countries in the world. The intention was to surge the input from $40-65 \%$ of GDP in the private sector along with intensifying foreign direct investment in from $3.8 \%$ to the level of $5.7 \%$ of GDP. Finally, there would be an increase in Saudi-ization in the oil and gas sectors (from $40-75 \%$ ) and the Public Investment Fund's assets (from SAR600 billion to more than SAR7 trillion) [10]. The government highlighted the danger of 'oil addiction' and advised to overcome and build a self-reliant economy. In enunciating Vision 2030, the government reiterated, "We have developed a case of oil addiction in Saudi Arabia". The government further reaffirmed that in the future, the country would not like to be at the mercy of external markets. The Vision, along with promoting the private sector as the main engine for social and economic development, also wants extensive revolution in transforming the economy towards multidimensional growth with minimal oil dependency [10].

The government has always been supportive of the Vision for the advancement of the nation. To ensure the implementation of Vision 2030, the government also streamlined process output to measure achievable goals. Emphasizing on the necessity of accountability, transparency, communication and public engagement, the Vision has been directed towards modernizing and uplifting the nation to a higher level.

\section{SUSTAINABLE DEVELOPMENT 2030}

In 1986, United Nations declared the 'right to development' and advised nation states to work towards overall development in every aspect of human life, while ensuring equal opportunities for all. This can be achieved by provision of access for all to basic resources such as health, education, nutrition and housing, employment and fair income distribution. All states should try worthwhile options to realize development. The constitution of World Health Organisation's definition of health reiterates the need for development of health. The AlmaAta declaration in 1978 further consolidated development of minimum health for everyone[11]. The Ottawa Charter for Health Promotion in 1986 laid emphasis on health development, Millennium Development Goals in 2000 highlighted the need to attain Universal Health Coverage for development. WHO Commission on Social Determinants of Health in 2000 and WHO Commission on Macroeconomics and Health in 2001, both placed health at the center of development. It is well-established that economic growth contributes to health development and better health in turn contributes to economic growth $[12,13]$.

In late 2012, United Nations System Chief Executives Board for Coordination (CEB), and World Bank Group agreed to strengthen their efforts to align their strengths and capacities for better cross-sectoral and cross-institutional thinking, coherence and coordination. This brought two world bodies together. In the meantime, the United Nations Conference on Sustainable Development was held in Rio de Janeiro in 2012. At the same time, civil society and non-governmental organizations formed people health movement (PHM) and advocated for the right to health. PHM organized a few health assemblies worldwide and they published an alternative health report of WHO. People's health assembly and people's charter for health voiced the need for right to health in 2000 . The interactions between United Nations and World Bank along with advocacy and the civil society's campaign for a sustainable world helped give birth to the sustainable development 2030.

The UN General Assembly established the Sustainable Development Goals (SDGs) 2030 in September 2015 with 17 universal goals to be achieved by 2030 for fostering a better world that is transforming towards sustainability and development [14]. While highlighting the links between peace, development and human rights, the sustainable development 2030 constitute an integrated and universal rightsbased agenda for sustainable development. It aims to balance economic growth along with social justice and environmental stewardship [15]. Sustainable development 2030 are an extraordinary action of global consensus to build a sustainable, desirable and progressivelyinterrelated world [16]. Health is included as a central agenda in the SDG3 aims to "ensure healthy lives and promote well-being for all at all ages" [14] and focused on the necessity to strengthen sustainability of health systems. Here, sustainability means resource mobilization together with allocative and technical efficiency improvements and politically acceptable development of organizational capacity of health system [17]. Since setting global health goals has a positive impact on overall development [18], the sustainable development 2030 provide an opportunity to build political commitment for a common agenda towards strengthening the health system. [19]. In 2016, WHO put in place the International Health Partnership (IHP) for UHC to bring together government and development partners for improved coordination of health system strengthening that will further help strengthen the UHC [19].

\section{DEVELOPMENT}


Development leads to progress towards positive change in human life and contributes to growth, quality of life and welfare. Internationally, development as an issue came to the forefront in the second half of the twentieth century. Development is not only linked to economic growth, but it also linked to socio-economic and political factors of a country. Amartya Sen developed the "capability approach", which has been used as parameter of the human development index. The 1986 UN declaration of the 'right to development' encouraged the state to play a key role in development, while pursuing goals that help bring in the right and provide equal opportunity for all. The state has been entrusted with the responsibility of ensuring and guaranteeing individual access to the basic resources for a dignified standard of living such as health, education, nutrition, housing, employment and fair distribution of income.

The path to sustainable development started in the 1970s but the Brundtland Report highlighted it at United Nations level in 1987 and linked it to the needs of present and future generations as a direction to development [20]. In realizing development, the state must maintain capacity to maintain its affairs [21]. State capacity is also linked to good governance [22] and it can be largely improved if the state develops an institutional environment to maintain necessary political support, capability and resources, and cooperation between groups [23].

\section{TRIPARTITE RELATION OF VISION 2030, SUSTAINABLE DEVELOPMENT 2030 AND DEVELOPMENT}

Saudi's Vision 2030 and NTP 2020 aims to transform the country into a sustainable one. Here, sustainable refers to its meaning in the context of development. The government took various steps to fulfil development goals. Vision 2030 is comprehensively linked with sustainability. The government wants to bring in a revolutionary transformation in the economy and gear it towards multidimensional growth and minimal oil dependence, building an affluent and sustainable economic development based on the country's strength and policies. The Sustainable Society Foundation developed the Sustainable Society Index (SSI). This index is based on social, economic and environment factors [24] that lead to sustainable development. Here sustainable development was focused as a multi-dimensional interpretation of development [24]. Vision 2030 is aligned to sustainable development indices, which have been pronounced to reflect the wishes, ambitions and situation of Saudi Arabia [24].

"Sustainable development is a transformation process in which the exploitation of resources, direction of investments, orientation of technological development and institutional change are reconciled and reinforces present and future potential, in order to attend to needs and future aspirations (...) it is that which attends to present needs without compromising the possibility of future generations attending their own needs" [25, p. 49]

Development indices are also linked to social, economic, political and environmental factors. The United Nations Conference in the 1990s on Environment and Development (Eco-92) focused on development more comprehensively and subsequently Agenda 21 was launched as the global agenda of sustainable development [20]. Development is denoted as "a state, process, well-being, progress, economic and human growth or ecological balance"[26, p. 11].

From the above analyses, we can conclude that both Vision 2030 and the sustainable development 2030 are development-oriented (Fig. 1). The government recognizes sustainable development 2030 are "incorporated into the government's detailed action plans and programs that are being developed and refined under the Vision 2030 framework" [27, p. 16]. It indicates the government is committed to implement sustainable development by linking it with the implementation of Vision 2030.

\section{Result}

\section{ROLE OF VISION 2030 IN RE-VITALIZING THE HEALTH SECTOR}

The Saudi public health system and the Ministry of Health were founded in $1925(\mathrm{MOH})$ and 1950, respectively. Since the 1970s, health sector was given priority in the National Development Plans that helped revolutionize this sector and resulted in enormous developments in the health status of the population [28]. Along with $\mathrm{MOH}$, there are other government as well as non-government agencies that have also contributed to the development process. As elsewhere, the KSA is also challenged by increasing expenditures in healthcare. The health and social sector was allocated $14 \%$ of the total budget, totaling SAR120 (US\$32) billion [29]. In 2014, overall health expenditure as a percentage of GDP was $4.68 \%$, and the per capita expenditure US\$1,147 [30].

The government is making an effort to overcome economic uncertainty by 2020 with the help of methods like broadening the economy, creating job opportunities for Saudi nationals in the private sector, and reducing expenses of the state [9]. Also, recently, the $\mathrm{MOH}$ has started new reforms according to the National Transformation Program (NTP) 2020 and the Saudi Vision 2030, focusing on development 
of the health system and improving the finance system, bringing about competency along with success in service delivery [8, 9]. To match the ever-changing needs of the society, the state has been ascertained to provide the best of services in the area of health, along with improving quality and minimizing costs [4]. Under the NTP, the government will strive to enhance infrastructure, manage health facilities, and maintain safe and quality standards [9]. The government is in the process of developing many medical cities (of 6,200 beds) across the country with investments of up to US\$4.3 billion intending to provide specialist healthcare services. The government has also undertaken the job to cover the geographical area. The plan is to build 38 new health centers with 9,100 beds and 23 new hospitals with 4,250 beds [31]. By 2020, the government is assumed to have built 264 hospitals with 70,694 beds, 2,750 PHCs and 27 specialist medical centers [31]. A recent initiative indicates that Ministry of Health is establishing a corporation under which six regional corporations will be created but only three regions will come under the implementation phase including East, Makkah and Riyadh regions.

The Vision highlighted that the public sector would engage in promotion of preventive care, reduction of infectious diseases and advising people to utilize primary healthcare. This will broaden partnership and assimilation between health and social care. The public sector will be involved in planning, monitoring and supervisory roles in healthcare. The government intends to work as public corporations to enhance privatization which would improve quality in the provision of healthcare. The government also intends to reduce the waiting time for appointments with specialists and consultants. Physicians will be trained to look after patients with modern diseases [8, 27].

Vision 2030 has prioritized the private sector and therefore the government is expecting and anticipating more investments here. With the help of various programs and changes in the economic field, the state is strengthening the private sector. It plans to improve the management system and generate standards for healthcare. The NTP intends to expand the functions of the private sector by concentrating on privatization and public-private partnerships (PPPs), improving the business environment, developing local markets, encouraging foreign direct investments (FDI) and supporting small and medium enterprises (SMEs) [9]. It is considered that there will be a rise in the expenses in the private sector from 25-35\% of GDP and a revenue jump of SAR4 billion from SAR300 million will be generated. It also foresees a spending of SAR23 billion by the $\mathrm{MOH}$ in the next five years, bringing about changes in primary healthcare, publicprivate partnership, and privatization of one of the medical cities [9]. By 2020, the government intends to privatize 2,259 PHCs and 295 hospitals. It wants to keep the planning, supervision and ownership of these institutes, but be managed by the private sector [9].

The government has also developed a national investment vision to increase investments, resulting in an added SAR2.3 trillion investments in the economy [9]. The vision targeted health sector privatization and projected increase of revenue of current 3 billion to 4 billion. It is also expected that by 2020, total private investment in the health sector will reach US\$100 billion (SAR375 billion), adding 12,500 new beds every year. The privatization move was aimed at increasing private sector participation in the healthcare sector from $25-$ $35 \%$ in line with the requirements of Vision 2030, which seeks to provide free and quality healthcare to 20 million Saudi citizens [32]. The government is undertaking different reform initiatives to boost the healthcare sector. Privatization of health sector is one of the focal points of government economic diversification activities to minimize public sector expenditures and reduce dependence on it. In 2015, more than US\$20.8 billion alone was contributed by the health sector to the country's GDP. It is expected that this sector will grow by $13.7 \%$ by 2025 . The government also planned to privatize all public hospitals and build public-private partnerships. At present, the public sector holds $80 \%$ of bed capacity, which will be expected to add 73,768 beds in 2020 and the private sector is expected to bring in 26,000 beds by 2020. It is reported that a private group of investors is building eight 130-bedded hospitals, 60 out-patient clinics, and other necessary amenities in a medical village in Riyadh. Meanwhile, the government is also constructing 36 new hospitals with 8,950 beds and two medical cities. Moreover, the government is planning to build another 18 hospitals with 9,904 beds over the next two years. In April 2018, Saudi Arabia announced an ambitious privatization plan, which includes 14 PPPs investments to be completed across 10 sectors, including healthcare by 2020. In July 2018, the government signed an agreement with the private sector for SAR 407 million loan to establish hospitals and medical facilities in Abha, Abu Arish, Buraydah, Dammam, Jeddah and Riyadh [4].

\section{ROLE OF SUSTAINABLE DEVELOPMENT 2030 IN RE-VITALIZING HEALTH SECTOR}

SDGs have 17 universal goals and 169 targets that are intertwined; for example, SDG2 is food security, SDG8 is micro-economic policy, SDG10 is to minimize inequality, SDG13 is building resilience for climate change, all of which are essential to accomplish SDG1 i.e ending poverty [33], thus contributing to SDG3 on health and wellbeing, indicating that a country must necessitate multidimensional and multisectoral policy interventions to achieve sustainable development [34]. SDG3 is related to other 16 SDGs that are also linked to social determinants of health. The development of health is dependent on its determinants. Population health will benefit from development in each of the determinants [35]. 
Target SDG3.8 focused on achieving universal health coverage (UHC) emphasizing on quality health services where all people and communities have easy access [14]. Strengthening the health system means advancement towards UHC [19]. A functional health system always works to support people, institutions and resources to improve, maintain or restore the health of the population. Health system strengthening allows to improve the system's performance [36] by maintaining and achieving quality, equity, efficiency, accountability, resilience and sustainability [19]. According to Kieny et al. strengthening the health system supports UHC and vice-versa [19]. These have been helping to achieve the sustainable development.

Kieny et al. suggests UHC can help achieve sustainable goals through investments in the health sector, while providing improved health outcomes for the whole population and contributing to SDG1[19]. Investments in the health sector to promote UHC will lead to enhanced economic development in line with SDG8. Investment in health leads to good health, which ultimately contributes to better educational outcome that fulfils SDG4. Equitable engagement in workforce leads to SDG5. Investment in health contributes to strengthening the health system which can provide impartial, responsible and amicable health services to the population that are linked to SDG16 [19]. Numerous health promotion and prevention actions are required beyond the health sector [37] and economically, it is estimated that US\$371 billion per annum is required to achieve targets for SDG3 only to 'ensure healthy lives and promote well-being' [38]. So, it can be concluded that implementation of sustainable development will enhance and revitalize the health system.

\section{Discussion}

Saudi Ministry of Health indicates it has strong commitment to fulfil Vision 2030 and engage the private sector in economic growth and sustainable development [39]. To achieve the goals laid out in the vision, the private sector will have to work with the public sector to improve the overall quality of healthcare services delivered, boost patient satisfaction, cut down on financial risks and to promote sustainable growth [39]. The10th development plan of the government gave importance to strengthening sustainable development [40]. The government also invited foreign investors and assured them 100\% ownership for their investment in the healthcare sector [41]. Investment alliances between national and global capital forged in the leadership of World Bank Group member International Finance Corporation (IFC) have critically contributed to the expansion of the global for-profit healthcare sector. Moreover, increased interest in healthcare and social sectors as potential growth areas has seen the global healthcare industry become a crucial target of private equity investments over the past decade [42].

To ensure alliance with the global capital and promotion of global healthcare industry the government in its pre-budget statement, some of these programs and schedules are revised to implement them to ensure they achieve the intended return, while development and modernization of government infrastructure and services continue [43]. Reiterating the government's clear vision and specific plans, the Crown Prince of Saudi Arabia has stated the country is working towards achieving laid-out goals and towards attaining economic stability, which in itself is a pillar of sustainable development [43]. Budget 2020 comes at a time of global economic challenges and protectionist policies that call for increased flexibility in the management of public finances and steps towards improving the economy's ability to overcome these hurdles. By taking advantage of the progress already achieved through various programs and building on the same, Saudi Arabia aims to strike a balance between pace of economic growth and the need for sustainable financial stability that ensures support for such growth. The private sector also becomes an engine of sustainable development by linking the public and private sectors [39].

Saudi Arabia aims to take the following action by linking sustainable development and Vision 2030 (Relevance of SDG 1 to Vision 2030):

1. Making healthcare easily accessible, based on geographical proximity, affordability and availability

2. Empowering citizens through the welfare system

3. Improve living conditions of the expatriate community

4. Improve value of healthcare services in terms of quality of outcomes, experience and cost

5. Strengthening the prevention program against health threats (public health system and health crisis management)

6. Better effectiveness and efficiency of the social services system [27, p. 36]

A close analysis outlines the importance of SDG3 in Vision 2030's strategic objectives and related initiatives, as follows:

Making healthcare services easily accessible; promoting value of healthcare services; promoting sports activities in society; improving quality of services provided in Saudi cities; substantially reducing air, noise, water and soil pollution; enhancing the nation's immunity towards drug abuse; promoting traffic safety; safeguarding the environment from natural threats; enhancing family involvement in preparing for their children's future; empowering citizens through the welfare system. 
As per the goals of Vision 2030, Saudi Arabia has laid out a patient-based National Healthcare Model (NHM) [27]. The features of NHM are as follows:

Strengthen healthcare services provided over the hotline; enhance services of the Saudi Center for Disease Control and Prevention; building comprehensive health polyclinics; provision of antenatal care services; establishing national referral network; setting up premarriage medical examination; provision of better home-based healthcare services; develop health research programs; developing schoolbased education programs; implementing safety programs at school [27, p. 46 ]. Saudi Arabia offers educational programs "Al Afia" on traffic safety to build community awareness [27]. Other ministries and government agencies took several initiatives to achieve SDG4 (sustainable educational development), SDG5 (gender equity), SDG8 (economic growth) and SDG12 (reduce pollution) that are aligned with Vision 2030. Vision 2030 incorporates several of the sustainable development into its agenda with key priorities in the three dimensions of social, economic and environmental sustainability. Continued political support from the highest level, a conducive policy environment, streamlined institutional systems and the ability to build on experience gained have all had positive impacts on the implementation of Agenda 2030 [27, p. 29]. The frameworks of sustainable development and Vision 2030, and the development trajectory so far have a significant degree of alignment.

Challenges facing the government are also enormous. Though the Saudi state was formed with a constitution in 1932 and the power base of the country is monarchical with Islamic values, the state is yet to build on governance in maintaining state affairs. The administrative system and institutional capacity of the state can be characterized as unduly complex due to over-centralization, nepotism, limited accountability, undue formality and intransigence, heavy workloads, overlap of functions, bureaucratic corruption, ubiquity of rules and procedures, fragile implementation and monitoring capacity, inefficient flow of information and inadequate information to make decisions. Moreover, a lack of sufficient inter-agency consultation or coordination, oversight of regulations, inadequate delegation of authority, complexities and delays in decision-making affected policy and the performance of administration. This is turn has had an effect on the functioning of the state, thus limiting the capacity of the state [44, 45]. Broadly, state capacity is linked to the political will of the government where the state successfully implement laws, manage the interest groups, government per se are adequate a task; including manpower and resources, fiscal capacity means government sustainable economic conditions, information management, logistic systems, communication networks, or human resource development and management and finally government performance outcome [21]. If we analyze the Saudi state of affairs, there is a mix of formal and informal elements in the state's management [46]. Moreover, in the recent years many factors like changes in the demography, life expectancy, disease patterns, sedentary lifestyles, expectations of consumers, costs of healthcare, oil revenues, delivery of services and more have made it a challenging task for the state to continue providing health services for no cost. Moreover, observations in the area of poor quality of services and greater health literacy renewed the demand for better healthcare. Although the government is capable of assigning resources to the health sector, it is stressed due to the ever-increasing expenditure and demands with resources remaining the same. During the implementation of goals and objectives, there seems to be an absence of markers that could gauge and calculate its success. So, it can be said that the state will face many challenges in realizing Vision 2030 and sustainable development the in Saudi context and to revitalize the Saudi healthcare system.

\section{Conclusion}

Saudi Arabia prepared Vision 2030 to outline promises to the nation, to uplift its economy and to overcome the challenges faced by the country. The government highlighted targeted goals to gain admiration and support from vast population groups that are young and dreaming of better lives and livelihoods. The government emphasized on economic development and advancement of the nation by diversifying from an oil-dependent economy into a non-oil product and services economy. Though the government has made significant improvement in the health sector, it needs to readjust policies and programs with changing disease patterns and financial conditions of the country. Overall, the government should improve the governance of health sector and extend the same to other sectors that will enhance state capacity. There is a need to improve service delivery by building cooperation and coordination of different services providers and other stakeholders. The government needs to strengthen healthcare through health human resources development, building partnerships between public and private sector, good management practices and efficient use of resources.

While the Saudi government is working to achieve the sustainable development 2030, it is also interested in engaging with other nations to share knowledge and experiences regarding global progress on the same. The government is also keen on improving collaboration among relevant government and non-government actors while strengthening the institutional framework in place to support the fulfilment of sustainable development. By setting aside substantial financial resources for the sectors, significant improvements have been made in the country's health and education outcomes. By chalking out a strategy to transform the Saudi economy and society, Vision 2030 has laid the foundation for achievement of the sustainable development 2030 while reiterating the government's commitment to do so. The realization of Vision 2030 is now also essential for the fulfilment of the sustainable development. The government has adapted the

Page $7 / 11$ 
sustainable development 2030 to the realities of the country by further realignment of its national programs, plans and strategies with global development targets, indicators and goals. Sustainable development and collaboration among public, private and non-profit stakeholders will likely be at the heart of all policy making and implementation if better collaboration among actors and strengthened institutional frameworks around Vision 2030 is achieved. Involved parties will have a better sense of ownership and commitment if they have a direct engagement with the pursuit of sustainable development 2030. Prudent reforms should be undertaken to accommodate the goals and objectives of Vision 2030 and sustainable development 2030 and to strengthen governance and state capacity so as to ultimately revitalize the Saudi healthcare system and improve population health.

Notes

1. Includes poverty, hunger, education, gender equality, water and sanitation, energy, economic growth, inclusive and sustainable industrialization and innovation, inequality, safe cities, sustainable consumption and production, climate change, sustainable use of water reservoirs, environmental protection, peace and justice, and partnerships.

2. including financial risk protection, access to quality essential health-care services and access to safe, effective, quality and affordable essential medicines and vaccines for all.

\section{Declarations}

\section{Ethics approval and consent to participate}

This study did not use human, hence ethical approval is required

\section{Consent for publication}

Both authors provided consent for publication

\section{Availability of data and material}

Not applicable

\section{Competing interests}

Authors declare no conflict of interest.

\section{Funding}

No Funding

\section{Authors' contributions}

RR contributed to the conception, design and prepared the manuscript, thorough review and finalization AQ helped in design, oversaw thorough review and finalization. Both authors read carefully and approved the final version of the manuscript.

\section{References}

1. Rahman R, Caulley D. The Methodology of a Study of the Regulatory Practices in the Private Health Care Sector of Bangladesh. Qualitative Research Journal. 2006;6(2):67-88.

2. Houser J. Nursing Research Sudbury. MA: Jones \& Bartlett Learning; 2011.

3. Karen E. On Saudi Arabia: Its People, Past, Religion, Fault Lines-and Future. New York: Vintage Books; 2013.

4. Rahman R, Alsharqi O. What drove the health system reforms in the Kingdom of Saudi Arabia? an Analysis. International Journal of Health Planning Management. 2019;34(1):100-10. 
5. Saudi. Arabia - Economic Forecasts - 2018-2020 Outlook, available on https://tradingeconomics.com/saudi-arabia/forecast accessed on 19July.

6. Alsayyad A, Nawar A. The social dimensions of Saudi Vision 2030: a paradigm shift. In. Brasília. DF - Brazil: International Policy Centre for Inclusive Growth; 2017.

7. Al-Kibsi G, Woetzel J, Isherwood T, Khan J, Mischke J, Noura H: Saudi Arabia Beyond Oil: The Investment and Productivity Transformation. In.: McKinsey Global Institute (MGI) 2015.

8. KSA.: Vision 2030. In. Riyadh Ministry of Planning and Economic Development 2016.

9. KSA. National Transformation Program 2020. In. Riyadh Ministry of Planning and Economic Development 2016.

10. Kinninmont J: Vision 2030 and Saudi Arabia's Social Contract Austerity and Transformation. In. London: Chatham House; 2017.

11. Rahman M. Human rights, health and the state in Bangladesh. BMC International Health Human Rights. 2006;6(4):1-12.

12. Lee K, Koivusalo M, Ollila E, Labonté R, Schrecker T, Schuftan C, Woodward D: WHO Commission on Social Determinants of Health Globalization, Global Governance and the Social Determinants of Health: A review of the linkages and agenda for action. In. Geneva: World Health Organization; 2007.

13. WHO: Macroeconomics and health: investing in health for economic development : executive summary / report of the Commission on Macroeconomics and Health. World Health Organization available on https://apps. who.int/iris/handle/ 10665/42463 accessed on 20Jan. 2020. In.: World Health Organization; 2001.

14. United Nations: Transforming our world: the 2030 Agenda for Sustainable Development. New York, United States: United Nations General Assembly, Resolution A/RES/70/1. United Nations General Assembly 70th session; New York: United Nations; 25 September. 2015 (https://sustainabledevelopment.un.org/post2015/transformingourworld). In.; 2015.

15. World Bank, United Nations Development Programme: Transitioning from MDGs to SDGs available on https://www.undp.org/content/dam/undp/library/SDGs/English/Transitioning\%20from\%20the\%20MDGs\%20to\%20the\%20SDGs.pdf accessed on 23 Dec. 2019. In.; 2015.

16. Costanza R, Fioramonti L, Kubiszewski I. The UN Sustainable Development Goals and the dynamics of well-being. Front Ecol Environ. 2016;14(2):20-2.

17. Olsen I. Sustainability of health care: a framework for analysis. Health policy planning. 1998;13(3):287-95.

18. Buse K, Hawkes S. Health in the sustainable development goals: ready for a paradigm shift? Globalization health. 2015;11(1):13.

19. Kieny MP, Bekedam H, Dovlo D, Fitzgerald J, Habicht J, Harrison G, Kluge H, Lin V, Menabde N, Mirza Z. Strengthening health systems for universal health coverage and sustainable development. Bull World Health Organ. 2017;95(7):537.

20. Soares J, Jair.,, Quintella RH. Development: an analysis of concepts, measurement and indicators. BAR-Brazilian Administration Review. 2008;5(2):104-24.

21. Rahman R. Regulation in the Doldrums: the State and the Private Health Care Sector in Bangladesh. Melbourne: La Trobe University; 2005.

22. Hall JS. Reconsidering the connection between capacity and governance. Public Organization Review: A Global Journal. 2002;2(1):23-43.

23. Luiz JM. The politics of state, society and economy. Int J Soc Econ. 2000;27(3):227-43.

24. Alshuwaikhat H, Mohammed I. Sustainability Matters in National Development Visions-Evidence from Saudi Arabia's Vision for 2030. Sustainability. 2017;9:e408.

25. Becker BK: A Amazônia pós ECO-92: por um desenvolvimento regional responsável. In: Para pensar o desenvolvimento sustentável. edn. Edited by Bursztyn M. Brasília: IBAMA/ENAP/Brasiliense; 1993.

26. Ribeiro MTF: Notas de aula do curso de doutorado em administração [Notas de aula]. Escola de Administração, Universidade Federal da Bahia, Salvador, Bahia, Brasil. ; 2005.

27. KSA: Towards Saudi Arabia's Sustainable Tomorrow First Voluntary National Review 2018 - 1439 available on https://sustainabledevelopment.un.org/content/documents/20230SDGs_English_Report972018_FINAL.pdf accessed on 14 Dec. 2019 presented at UN High-Level Political Forum 2018 "Transformation towards sustainable and resilient societies" July 9-18, 2018, New York. In.; 2018.

28. Almalki M, Fitzgerald G, Clark M. Health care system in Saudi Arabia: an overview. Eastern Mediterranean Health Journal. 2011;17:784-93. 
29. Trading Economics: Government budget by country available on https://tradingeconomics.com/saudi-arabia/government-budget accessed August 7. 2017. In.; 2017.

30. Du L, Lu W. U.S. Health-Care System Ranks as One of the Least-Efficient available on https://www.bloomberg.com/news/articles/2016-09-29/u-s-health-care-system-ranks-as-one-of-the-least-efficient accessed on 14August 2017. In.; 2016.

31. Oxford Business Group: The Report: Saudi Arabia. 2016 available on https://oxfordbusinessgroup.com/overview/hale-and-heartyinitiatives-seek-expand-access-and-improve-quality-care accessed on 7th Feb 2019. In. Riyad: Oxford Business Group; 2016.

32. Privatization to add 50,000 beds to health-care system available on https://www.google.com.sa/search?q= (http\%3A\%2F\%2Fsaudigazette.com.sa\%2Farticle\%2F515116\%2FSAUDI-

ARABIA\%2FPrivatization)\&rlz=1C1CHBF_enSA725SA725\&oq= (http\%3A\%2F\%2Fsaudigazette.com.sa\%2Farticle\%2F515116\%2FSAUDIARABIA\%2FPrivatization)\&aqs=chrome..69i57.1228j0j7\&sourceid=chrome\&ie=UTF-8 accessed on Nov 22018.

33. ICSU ISSC. Review of the Sustainable Development Goals: The Science Perspective. In. Paris: International Council for Science (ICSU); 2015.

34. Tangcharoensathien V, Mills A, Palu T. Accelerating health equity: the key role of universal health coverage in the Sustainable Development Goals. BMC Med. 2015;13(1):101.

35. Mirza Z. Sustainable Development Agenda 2030 thrives on health. EMHJ-Eastern Mediterranean Health Journal. 2016;22(10):711-2.

36. Kutzin J, Sparkes SP. Health systems strengthening, universal health coverage, health security and resilience. Bull World Health Organ. 2016;94(1):2.

37. Deloitte. '2019 Global Health Care Sector Outlook: Shaping the Future'. London: Deloitte. /Life-Sciences- Health-Care/gx-Ishc-hcoutlook-2019.pdf accessed 20 Nov 2019. In.; 2019.

38. Stenberg K, Hanssen O, Edejer TT-T, Bertram M, Brindley C, Meshreky A, Rosen JE, Stover J, Verboom P, Sanders R. Financing transformative health systems towards achievement of the health Sustainable Development Goals: a model for projected resource needs in 67 low-income and middle-income countries. The Lancet Global Health. 2017;5(9):e875-87.

39. MOH: Private sector participation available on https://www.moh.gov.sa/en/Ministry/vro/Private-SectorParticipation/Pages/default.aspx Accessed o 27 November. 2019. In. Riyadh: Ministry of Health 2019.

40. KSA. COMPREHENSIVE GROWTH STRATEGY: KINGDOM OF SAUDI ARABIA. In. Riyadh: Ministry of Economy and Planning; 2014.

41. Colliers International. Kingdom of Saudi Arabia Healthcare Overview 2018. In. Dubai: Colliers International; 2018.

42. Lethbridge L. Health Care Reforms and the Rise of Global Multinational Health Care Companies. In. London: PUBLIC SERVICES INTERNATIONAL RESEARCH UNIT (PSIRU; 2015. .

43. Saudi Press Agency: We Will Continue Building, Progress as the Budget for the Year 2020 Enhances Vision 2030 Objectives, says HRH Crown Prince 2 Riyadh https://www.spa.gov.sa/viewfullstory.php?lang=en\&newsid=2008949 accessed on 14th December. 2019. In.; 2019.

44. Hanson JK, Sigman R: Leviathan's latent dimensions: measuring state capacity for comparative political research. In: APSA 2011 Annual meeting paper: 2013; 2013.

45. Gan Integrity: Saudi Arabia Corruption Report -Snapshort available on https://www.ganintegrity.com/portal/country-profiles/saudiarabia/ accessed on 29December. 2019. 2019.

46. Radnitz S. Informal politics and the state. Comparative Politics. 2011;43(3):351-71.

\section{Figures}




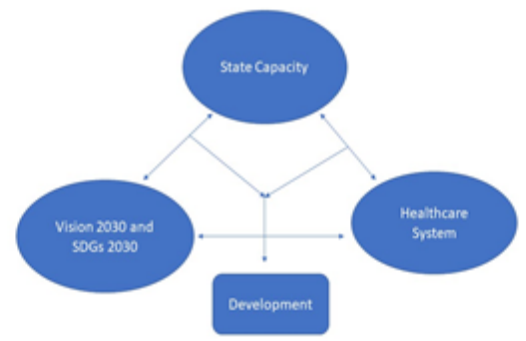

\section{Figure 1}

Interrelation of Vision 2030, Sustainable Development 2030, State Capacity and Healthcare System 